Man and Nature

L'homme et la nature

\title{
Goethe's Concept of Acting: Reactionary or Progressive?
}

\section{David G. John}

Volume 11, 1992

URI : https://id.erudit.org/iderudit/1012673ar

DOI : https://doi.org/10.7202/1012673ar

Aller au sommaire du numéro

Éditeur(s)

Canadian Society for Eighteenth-Century Studies / Société canadienne d'étude du dix-huitième siècle

ISSN

0824-3298 (imprimé)

1927-8810 (numérique)

Découvrir la revue

Citer cet article

John, D. G. (1992). Goethe's Concept of Acting: Reactionary or Progressive? Man and Nature / L'homme et la nature, 11, 77-87. https://doi.org/10.7202/1012673ar

Copyright (c) Canadian Society for Eighteenth-Century Studies / Sociéte canadienne d'étude du dix-huitième siècle, 1992
Ce document est protégé par la loi sur le droit d'auteur. L'utilisation des services d'Érudit (y compris la reproduction) est assujettie à sa politique d'utilisation que vous pouvez consulter en ligne.

https://apropos.erudit.org/fr/usagers/politique-dutilisation/ 


\section{Goethe's Concept of Acting: Reactionary or Progressive?}

Goethe moved to Weimar in 1775 . His experiences there as a theatre director began soon after with his leadership of a noteworthy amateur group of theatre lovers (the Liebhabertheater), followed by his directorship of the Weimar court theatre from 1791 until 1817, during which time he directed 600 plays in over four thousand performances. ${ }^{1}$ Goethe was responsible for all aspects of theatre in Weimar and the neighbouring towns and cities visited by the Ducal company. He hired the actors and approved the repertoire, contributed his own original dramas, prologues, theoretical commentaries, and performance critiques, along with providing translations and adaptations and often designing sets. In short, Goethe was a theatre man of grand proportion. To understand his concept of acting and his contribution to the art and technique of acting in the age, we must first survey developments in eighteenth-century acting technique before Goethe; and then assess Goethe's concept of acting against this background. ${ }^{2}$

Controlled, regulated acting was still in its infancy on German stages when Goethe assumed the directorship at Weimar. Two main streams lay behind: the tradition of improvisation which characterized performances of itinerant troupes until about 1770; and the declamatory style, copied from the French, which held sway in the many court theatres, where foreign troupes were usually engaged. Some of the more ambitious itinerant troupes, such as those of Caroline Neuber and Johann Schönemann, also performed in this style, but they had little guidance in the form of written instructions for actors. ${ }^{3}$ The first important milestone in the development of controlled German acting was reached by the Schönemann troupe through the efforts of Conrad Ekhof, one of their number who by 1770 established himself as the premier actor of his time and gained the unofficial title 'father of German acting.' He established an academy within the Schönemann troupe which met bi-weekly in 1753-54 to discuss the repertoire and all aspects of performance, in his words 'die Grammatik der Schauspielkunst [zu] studieren. ${ }^{4}$ The intention behind Ekhof's phrase 'Grammatik der Schauspielkunst' was to establish a set of guidelines for actors, telling them how to act, in other 
words, a set of norms by which professional performance could be measured. Ekhof saw two main dimensions to the actor, both of which must be developed to achieve top performance: the 'Seelenkräfte' or 'spiritual forces' and 'die mechanischen Theile der Schauspielkunst." These mechanical aspects included things that could be learned: appropriate expression, pose, gesture, position, movement and intonation. Only then should an actor attempt to master the subtleties of the spirit, the 'Seelenkräfte,' and many actors never came so far as to approach this dimension. Ekhof was the first German to make a clear distinction between the conventional and the unique in performance, a distinction that would remain basic to all further developments in German acting technique. Until mid-century, actors relied mostly on their innovative talents, which led to originality and uniqueness in performance, but also resulted very often in uncontrolled, individualistic display without conscious reflection on artistic presentation. By stressing the need to begin with the mechanical parts, Ekhof clearly felt that German actors first needed to establish convention before moving to individuality and uniqueness.

We know that the basic guide for academy sessions was Lessing's translation of Francesco Riccoboni's L'art du théâtre (Die Schauspielkunst, 1750), which was a detailed set of instructions for actors, somewhat removed from the French declamatory style. Riccoboni suggests that the essence of good acting lies in the gift of insight or understanding. This alone makes a great actor, and without it nothing more can result than mediocrity. ${ }^{6}$ Like Ekhof, Riccoboni advocated a specific sequence for learning to act, with emphasis on movement first, then voice and declamation. Only later should the pupil attempt to add the elusive 'Einsicht' or insight, and with it a more sophisticated sense of harmonious performance in relation to the other players, the script and the space.

Lessing was the first to attempt to write a set of acting rules in German. Starting out from Riccoboni's L'árt du théâtre he began to write an instruction book in 1754 which promised to cover the complete fundamentals of physical eloquence ('die Grundsätze der ganzen körperlichen Beredsamkeit'), including body movement, gestures, voice tones, posture and position. ${ }^{7}$ This ambitious promise went unfulfilled as the work remained a twenty-page fragment with no direct effect on the actors Lessing so wished to assist. ${ }^{8}$ Still, Lessing communicated the ideas during his active participation in the Hamburg Entreprise of 1767-68 (the first attempt to create a self-supporting public theatre in German territory), and although he was convinced of the need for a guidebook in basic technique and systematic direction, from his reading and translation of Diderot he also nurtured the notion of an actor's freedom on stage: 'Some parts of the performance one must leave almost entirely up 
to the actor. ${ }^{9}$ Movement and gesture could indeed be mastered through systematic direction and practice, but no system of rules could replace innovative genius. Still, like Ekhof, Lessing thought that the development of uniform acting conventions had to come first. The last article of the Dramaturgie concludes: 'We have actors, but no professional art of acting ... there is a lot of prattle in various languages about what this is, but when it comes to a well-known, clear, precise set of rules according to which an actor's weakness or strength can be measured, then I could hardly think of two or three. ${ }^{10}$ Lessing doesn't indicate which he is thinking of, but certainly none of them was German.

One of the few contemporaries who thought little of Ekhof's acting or approach, or of Lessing's belief in rules, was Friedrich Ludwig Schröder. Although Ekhof is called the father of German acting, Schröder rivalled him in renown, but for entirely different reasons. He was stunning in improvisation and acrobatics, and showed pure innovative comic genius. He thought Ekhof stiff and talentless and often mocked his serious approach, and when Schröder's troupe principal Ackermann eagerly grabbed the opportunity to play in the Hamburg Nationaltheater in 1767, Schröder refused to go, preferring instead to join Joseph von Kurz of Vienna on tour. Schröder and Kurz were kindred spirits, perhaps the last of the century's great improvisational talents. Schröder insisted that freedom, not restriction, was the essence of effective acting, as he expresses here:

You do well to reject out of hand the imitative, aping art of copying. One independent step is worth more than limping for miles on borrowed crutches. The art of acting is very devalued if one conceives of it simply within terms of imitating extant examples. At most one admires the effort of the copier, but only those can lay claim to the name artist who create their own forms (Gebilde) freely from the fullness of their fantasy. An actor is not an antiquarian who takes figures from the past and reproduces them! $!^{11}$

Central to Schröder's concept of the actor as artist is the ability to create through fantasy and intuitive genius instead of slavishly copying models and adhering to prescribed technique. While Ekhof and Lessing may well have agreed with that, unlike Schröder they were not willing to take the risk he accepts by encouraging the actor first and foremost to create something new each time he performs. This was of course common in the extemporized theatre tradition which retained Schröder's allegiance, but by the seventies and eighties, with complete texts forming the basis of most performances, such freedom was more difficult to maintain. Still, even within this mode, Schröder defended his position, and despite his 
own evolution toward text-based performance, he tirelessly insisted on the primacy of the actor:

The actor must even overcome the poet, and the greater that poet, the more difficult the struggle, the more glorious the victory. Woe be it for art if audiences say on their way home: 'How beautiful the sets were, how magnificent the costumes!' Woe to the actor if, instead of leaving the theatre in silence with tears in their eyes or a smile on their lips, the audience says: 'The play is beautifully written!' Then they have attended a reading society, [not a theatrical performance]. ${ }^{12}$

What counts for Schröder, what counts for true theatre, is not costume, not props, not scenery, not text; what counts, the only thing that counts, is the actor's ability to move the audience. How he does it is irrelevant. Failure to do it is fatal. The position is extreme, but in the face of a coming wave of fashion in the opposite direction, understandable.

From about 1770, we must mark an important change in the theatre scene which would alter its direction completely and have an enormous effect on acting. Permanent public theatres were founded in virtually every major German city, with fixed companies of professional actors who were subject to precise direction, who acted according to written, usually published scripts and texts, who were fined for ignoring or abusing regulations, and who finally had to answer not only to the director but to the state censor as well. This was a complete change from the previous decades of itinerant troupes who enjoyed enormous freedom to improvise, often acted from scant scenarios, had little or no direction and few controls over their performance. The result was a sudden change in the profession of acting, and at the same time a virtual flood of guidebooks on how to act. Between 1770 and 1818 at least two dozen guides for German actors and orators appeared, the most important without question Johann Jakob Engel's Ideen zu einer Mimik, first published in 1785, reprinted many times thereafter, and translated into several languages. Engel's work was a conscious response to Ekhof's and Lessing's plea for a standard guide and became an authoritative document. It is a weighty and thorough compendium of rules for actors, two volumes of precise directions with many illustrations on all aspects of acting technique. Engel's work is guided by one fundamental principle:

Imitation, or representation, of Nature ... is an insufficient principle in itself. Nature achieves perfection in many areas which art can only grasp carefully and 
represent truthfully. But many things in Nature do not reach the degree of perfection they should, even with her best efforts... It is then art's duty, by observing as closely as possible, and by following principles drawn from these observations, to improve upon Nature's errors, to correct what is wrong.... ${ }^{13}$

Engel's goal for actors was to depict not just nature but idealized nature and harmony. In describing how this is to be accomplished he uses the words 'instinct' and 'genius' ('Instinct' and 'Genie'), but to these he adds 'the precisely formulated rule' ('die deutlich gedachte Regel') ${ }^{14}$ and, like his forerunners Ekhof and Lessing, it is on these rules of acting that Engel in the end lays most emphasis.

In Weimar, Goethe was very much aware of his forerunners. He refined his own ideas through active involvement with the amateur theatre group (Liebhabertheater) and then as director of the court theatre. With the Liebhabertheater, Goethe encouraged a good deal of extemporization, particularly in comedy. ${ }^{15}$ In their repertoire we see that some entire evenings were given over to extemporized performance, but as time wore on Goethe became more and more wary of such freedom and at the end of the century, in thoughts produced with Schiller which he subsequently entitled 'On dilettantism' ('Über den Dilettantismus,' 1799) Goethe says, "The dilettant is to art as the bungler to craftsmanship. A prerequisite for art is that it is learned by rules and practiced according to laws.... ${ }^{16}$ Goethe always retained a healthy respect for extemporized play in acting, but such licence was gradually reduced to virtual insignificance in his later career.

Goethe's own set of rules, in so far as he collected them in one place, are his Regeln für Schauspieler (Rules for Actors, 1803; first published 1824). He referred to this collection as a grammar ('Grammatik') for actors, the same term Ekhof had used. ${ }^{17}$ These rules followed fast on the heels of a prescriptive volume for actors by his colleague Friedrich Einsiedel, Guidelines for a Theory of Acting (1797), to whose genesis Goethe had contributed considerably. Einsiedel characterized his book as 'merely a draft plan of a more complete structure' ('blos Skizzen zu dem Plane eines ... vollständigeren Gebäudes,'), but he never produced a further version. ${ }^{18}$ Goethe's Regeln can be seen as the next step, but the ninety-one brief sub-sections and many detailed instructions on aspects of gesture, movement, voice and delivery which comprise the work, are not an extensive grammar for actors to compare with Engel's or other predecessors.' Goethe's actors, as most of their contemporaries, continued to rely heavily on the guides in existence by 1790 , and Goethe's own belief in the importance of strict rules to guide performance is reflected in this comment on his star pupil Pius Alexander Wolff: 'How he acted! How 
reliable he was! How secure! - It was impossible for me to detect even a sign of offence against the rules I had implanted in him. ${ }^{19}$ But beyond the details of individual acting technique, Goethe's predominant emphasis was on harmonious beauty, which was to be projected by the entire cast. This emphasis is clear in the Regeln, it is different from much that had gone before, and it is important for an understanding of his concept of acting.

Several sections of the Regeln illustrate this underlying philosophy. In the section 'Position and Motion on Stage' ('Stellung und Bewegung des Körpers auf der Bühne') we see that the sense of harmony begins with the individual player:

The actor should first remember that he should not only imitate Nature, but should represent it as an ideal, and so he must combine truth with beauty in his presentation. Hence, every part of the body should be under his control so that he can use every limb freely, harmoniously and with grace for the expression intended. ${ }^{20}$

Despite the fact that Goethe insisted repeatedly that nature was the primary guide, the desired effect of harmonious, idealized truth was in a sense really the same as advocating artificiality. As he goes on, Goethe's idea of theatre seems equivalent to the living depiction of a beautiful painting:

The theatre should be seen as a tableau without figures, which the actors by their presence bring to life.... Therefore actors should never play too closely to the wings, neither should they enter the proscenium area. This is the greatest transgression, for the figure then steps out of the space in which she contributes with the other actors in the set to a unified whole. ${ }^{21}$

In the original, Goethe speaks of a 'Tableau ... worin der Schauspieler die Staffage macht.' The word 'Staffage' can mean 'accessories' or 'decoration,' but in the late eighteenth and early nineteenth centuries, it was used usually in connection with painting to mean a group of humans or animals whose presence effectively brought the scene to life in a plastic work. ${ }^{22}$ Goethe's concept of acting is strongly visual; it puts the harmonious ideal whole before the actors' individual authority and impact. In his Proserpina essay, Goethe went so far as to say that the movements of the body 'should remind us of the dignity of sculpture. ${ }^{23}$ Einsiedel's Guidelines for Acting, on which Goethe had collaborated, repeatedly invokes such concepts as 'the theatrical transformation of the poet's 
images into statues,' 'analogies from the plastic arts' and 'mimic-pictorial depictions. ${ }^{24}$ Often in Goethe's Regeln this static approach is reinforced.

We are reminded of ideas Goethe had shared with Wilhelm von Humboldt just a few years earlier, as expressed in Humboldt's letter 'On the present French stage,' (1799) which Goethe published as an essay in his Propyläen. ${ }^{25}$ Humboldt there singled out for admiration the 'malerische Gestalt' of the Parisian actor François Joseph Talma, claiming 'Whether he be sitting, standing or kneeling, the painter will always be interested in studying his poses. ${ }^{26}$ Even in movement, claims Humboldt, the French actors maintained this pictorial quality: 'In gestures French actors ... are more pictorial (mehr malend), than Germans who use almost exclusively expressive gestures.... ${ }^{27}$ The term 'expressive gestures' ('ausdrückende Gebehrden') was part of the standard contemporary terminology to describe gestures, which could be indicative ('zeigend'), imitative ('nachahmend') or expressive ('ausdrückend'). Humboldt, and by extension Goethe, criticized German actors for not going beyond the use of expressive gestures, but these were commonly understood until then to be the highest form of gestural expression. ${ }^{28}$ In the Regeln, Goethe goes beyond that, repeatedly using the term 'mahlende Gebährde' (pictorial gesture), as in these examples: 'The pictorial gesture with the hands must be made rarely, but should not be ignored completely' ('Die mahlende Gebährde mit den Händen darf selten gemacht werden, doch auch nicht ganz unterlassen bleiben;') $)^{29}$ and 'It must be depicted as if it were not being done intentionally' ('Es muß gemahlt werden, doch so, als wenn es nicht absichtlich geschähe;' $)^{30}$ and a specific example relating to Schiller's Braut von Messina: 'When the actor says "I" at this point, he can properly point to his breast with a pictorial gesture of the hand' ('Hier kann das erste Ich füglich mit der mahlenden Gebärde durch Bewegung der Hand gegen die Brust bezeichnet werden.') ${ }^{31}$ Goethe also advocates in the Regeln that entire series of gestures be arranged with specific regard to pictorial quality. In one section he writes, 'The actor on the right must act with his left hand, and vice versa, the actor on the left must act with his right, so that the chest is obscured as little as possible by the arm. ${ }^{32}$ In insisting that actors stage right use their left hands to act, Goethe goes completely against the grain of eighteenth-century acting technique which insisted that first and foremost the right hand be used for gestures. ${ }^{33}$ Clearly, Goethe was more concerned about the harmonious visual balance, the pictorial equilibrium on stage, than this tradition. Humboldt and Goethe are saying that there is an even higher level of gesture than the 'expressive,' that is, the 'malerische Geste' which transcends the play itself to become a lingering static image. This was indeed a new direction and even a new dimension 
in German acting. Some modern critics have translated Goethe's repeated use of the word 'malerisch' simply as 'descriptive.' I believe that this is an insufficient translation which severely limits our understanding of the dimensions of the term. ${ }^{34}$

Was Goethe's concept of acting reactionary or progressive? Goethe was certainly not a reactionary. He gave full credit to, and learned much from, the strengths of the early itinerant companies, especially their talent to improvise. Like Schröder, he cherished the notion of uniqueness in performance, though Goethe would not give the free rein that Schröder did to his actors. Goethe further assumed from his predecessors in acting theory the notion of idealized nature, and also his belief in the necessity of explicit rules for actors. His own attempt to write a set of rules shows how much he was indebted to earlier tries. He was not reactionary, for he weighed, absorbed and used the strengths of the acting tradition before him. But was he progressive? This question is much more difficult to answer. There is no doubt that Goethe's overriding emphasis on harmony and visual coherence produced in Weimar unique accomplishments in German acting and theatre. But at the same time Goethe's style reminds us of Schröder's horror at the thought of theatre-goers praising the text, costumes and scenery, not the actors or the play. Indeed, whether the conversion of drama, an essentially active art form, to the realm of pictorial art, an essentially static one, is progressive, is something that many a play-goer might wish to question.

DAVID G. JOHN

University of Waterloo

\section{Notes}

14,136 to be precise. Details from Carl August Hugo Burkhardt, Das Repertoire des Weimarischen Theaters unter Goethes Leitung 1791-1817 (Hamburg u. Leipzig: Voß, 1891), p. XXXV.

2 Many sources record evidence of Goethe's responsibilities and style. See in particular Heinz Kindermann, Theatergeschichte der Goethezeit (Wien: Bauer, 1948), pp. 552-730, Burkhardt, Das Repertoire ..., and Gisela Sichardt, Das Weimarer Liebhabertheater unter Goethes Leitung (Weimar: Arion, 1957).

3 My principal source to establish a bibliography of German treatises on acting in the eighteenth century was Dene Barnett's The Art of Gesture: The Practices and Principles of 18th Century Acting (Heidelberg: Winter, 1987). In 1727 Franciscus Lang had published in Munich an important practical manual of acting, Dissertatio de actione scenica, cum Figuris eandem explicantibus, transl. by Alexander 
Rudin, Abhandlung über die Schauspielkunst (München: Francke, 1975), but it did not become well known. Then there was only Gottsched's compendious Ausführliche Redekunst (1739), an authoritative work on rhetoric and eloquence for decades, but with little on gesture and movement for actors; and Christian Wiedeburg's book on eloquence (Einleitung zur Wohlredenheit, 1748) which also concentrates on oratory rather than acting.

4 Heinz Kindermann, Conrad Ekhofs Schauspieler-Akademie (Wien: Rohrer, 1956), 21.

5 Kindermann, $C E, 17 \mathrm{f}$.

6 German translation in Lessing, Werke. Vollständige Ausgabe in 25 Teilen, Hrsg. v. Julius Petersen et al. (Berlin: Bong, [1925]), X, 88f.: 'Das, was in der Tat den Namen Einsicht verdienet, ist die vorzüglichste theatralische Gabe. Sie allein macht große Schauspieler; und ohne sie kann man niemals was anders als einer von den mittelmäßigen Leuten werden....' Translations into English throughout the text and notes are my own.

7 Diderot was also important for this phase of Lessing's development. Lessing translated several Diderot works in two volumes: Das Theater des Herrn Diderot, 1760.

8 See Lessing, Werke in 8 Bänden, Hrsg. v. Herbert G. Göpfert (München: Hanser, 1970-79), IV (1973), 723-33. I have used this edition because it is reliable, modern, and accessible to most. Since it does not contain Lessing's translations of Riccoboni and Diderot, however, I have also turned to the Petersen/Bong edition as necessary (notes 6 and 9).

9 'Es gibt Stellen, die man fast ganz und gar dem Schauspieler überlassen sollte.' Lessing, Das Theater des Herrn Diderot, Der natürliche Sohn in Werke (Berlin: Bong, [1925]), IX, 110.

10 'Wir haben Schauspieler, aber keine Schauspielkunst... Allgemeines Geschwätze darüber, hat man in verschiendenen Sprachen genug: aber spezielle, von jedermann erkannte, mit Deutlichkeit und Präzision abgefaßte Regeln, nach welchen der Tadel oder das Lob des Akteurs in einem besonderen Falle zu bestimmen sei, deren wüßte ich kaum zwei oder drei.' Werke (München: Hanser, 1970-79), IV (1973), 697.

11 'Sie thun sehr wohl daran [sagte Schröder], die Affen- und Afterkunst des Copirens schlechthin zu verwerfen; Ein selbständiger Schritt vorwärts ist mehr werth, als meilenweit auf fremden Krücken zu hinken. Die Schauspielkunst wird sehr herabgewürdigt, wenn man nur den Begriff der Nachahmung vorhandener Muster damit verbindet. Allenfalls staunt man den Fleiß des Copisten an, aber auf den Namen eines Künstlers darf nur Derjenige Anspruch machen, der aus der Fülle seiner Phantasie eigene Gebilde frei erschafft. Ein Schauspieler sei kein Antiquar, der seine Gestalten durch Tradition empfängt und wiedergibt!' Friedrich Ludwig Schmidt, Denkwürdigkeiten des Schauspielers, Schauspieldichters und Schauspieldirektors. 2 Thle. Hrsg. v. Hermann Uhde (Hamburg: Mauke, 1875), $206 f$.

12 'Selbst den Dichter muß der Schauspieler überwinden; je größer jener, um so schwerer der Kampf, um so glorreicher der Sieg. Wehe der Kunst, wenn der Herausgehende sagt: "Wie schön war die Decoration und wie trefflich das Costüm!" Wehe dem Schauspieler, wenn, statt mit Thränen im Auge oder mit Lächeln auf den Lippen wortlos das Theater zu verlassen, der Zuschauer laut sagt: “Das Stück ist schön geschrieben!" Dann war es eine Lesegesellschaft, die er verlassen hat.' Schmidt, Denkwürdigkeiten, 136. 
13 'Aber Nachahmung, Darstellung der Natur ist ... ein Grundsatz der nirgend hinreicht. Der Natur gelingt Manches in einer Vollkommenheit, dass die Kunst nicht weiter thun kann, als es sorgfältig aufzufassen und getreu wieder darzustellen; aber Manches erreicht bei jener, auch wo sie am besten wirkt, den Grad der Vollkommenheit nicht, den es sollte ... und da erfordert denn die Pflicht der Kunst, aus einer gesammelten Menge von Beobachtungen, oder nach Grundsätzen die aus diesen Beobachtungen gezogen sind, die Fehler der Natur zu verbessern, das Falsche zu berichtigen....' Johann Jakob Engel, Ideen zu einer Mimik. Bd. 7, 8 of Schriften (1801-06), 12 Bde.; rpt. (Frankfurt am Main: Athenäum, 1971), I, 18-20.

14 Engel, Ideen, I, 23, 24f, $29 f$.

15 For examples, see Sichardt, Das Weimarer Liebhabertheater ... pp. 102, 146.

16 'Der Dilettant verhält sich zur Kunst, wie der Pfuscher zum Handwerk. Man darf bey der Kunst voraussetzen, daß sie gleichfalls nach Regeln erlernt und gesetzlich ausgeübt werden müsse....' Werke, Weimar Ausgabe (Tokyo: Sansyusya; Tübingen: Niemeyer), I, 47 (1975), 322.

17 The reference is found in his Tag- und Jahreshefte of 1803 where he refers to the genesis of the Regeln (Weimar Ausgabe, I, 35, 148). The Regeln are available in the Weimar Ausgabe I, 40, 139-68.

18 Grundlinien zu einer Theorie der Schauspielkunst (Leipzig: Göschen, 1797), 11.

19 'Aber wie spielte er! wie war er sicher! wie war er fest! - Es war mir unmöglich, ihm nur den Schein eines Verstoßes gegen die Regeln abzulisten, die ich ihm eingepflanzt hatte....' Sämtliche Werke nach Epochen seines Schaffens, Hrsg. v. Karl Richter et al., Bd. 19, Johann Peter Eckermann. Gespräche mit Goethe in den letzten Jahren seines Lebens, Hrsg. v. Heinz Schlaffer (München: Hanser, 1986), 268.

20 'Zunächst bedenke der Schauspieler, daß er nicht allein die Natur nachahmen, sondern sie auch idealisch vorstellen solle, und er also in seiner Darstellung das Wahre mit dem Schönen zu vereinigen habe. Jeder Theil des Körpers stehe daher ganz in seiner Gewalt, so daß er jedes Glied gemäß dem zu erzielenden Ausdruck frei, harmonisch und mit Grazie gebrauchen könne.' (Regeln, Weimar Ausgabe, I, $40,153 f$.)

21 'Das Theater ist als ein figurloses Tableau anzusehen, worin der Schauspieler die Staffage macht.... Man spiele daher niemals zu nahe an den Kulissen.

Ebensowenig trete man ins Proszenium. Dies ist der größte Mißstand; denn die Figur tritt aus dem Raume heraus, innerhalb dessen sie mit dem Scenengemählde und den Mitspielenden ein Ganzes macht.' (Regeln, Weimar Ausgabe, I, 40, 166f.; emphasis mine)

22 See examples in Grimm, Deutsches Wörterbuch, 10, 514-15.

23 '... an die Würde der Plastik ...' Werke, Weimar Ausgabe, I, 40, 117.

24 Einsiedel, Grundlinien, pp. 20, 27 and 59: 'Die theatralische Verwandlung der Bilder des Dichters in Statuen'; 'Analogien aus der bildenden Kunst'; and 'mimisch-bildliche Schilderungen.'

25 'Über die gegenwärtige Französische Bühne, 1799.' Propyläen, III, 1 [1800], 66-109. See Humboldt, Werke, Hrsg. v. Albert Leitzmann (1904; photomechanischer Nachdruck Berlin: de Gruyter, 1968), II, 377-400.

26 'Er mag sitzen, stehen, niederknien, so wird es der Maler immer werth finden diese Stellungen zu studieren.' Humboldt, Werke, II, 379. 
27 'In dem Gebehrdenspiel ist der Französische Schauspieler ... mehr malend, als der Deutsche, der nur fast ausdrückende Gebehrden kennt....' Humboldt, Werke, II, 385.

28 See Dene Barnett's exhaustive work on the subject in The Art of Gesture, especially his basic distinctions among gesture types, pp. 27-38.

29 Werke, Weimar Ausgabe, I, 40, 158; emphasis mine.

30 Werke, Weimar Ausgabe, I, 40, 159; emphasis mine.

31 Werke, Weimar Ausgabe, I, 40, 159; emphasis mine.

32 'Wer auf der rechten Seite steht, agire mit der linken Hand, und umgekehrt, wer auf der linken Seite steht, mit der rechten, damit die Brust so wenig als möglich durch den Arm verdeckt werde.' Werke, Weimar Ausgabe, I, 40, 160.

33 See many examples in Barnett, The Art of Gesture, Chapter III, Sections 11 and 12, pp. 95-112 and elsewhere.

34 For example, in his translation of the Regeln, appended to his Goethe and the Weimar Theatre (Ithaca: Cornell U. Press, 1978), Marvin Carlson consistently uses 'descriptive' for the original 'mahlend.' This by no means seriously diminishes the value of his excellent account of Goethe in Weimar. 